\title{
A Rare Cause of Acute Appendicitis: Enterobius vermicularis
}

\section{Nadir Bir Akut Apandisit Sebebi: Enterobius vermicularis}

\author{
(1) Mehmet Patmano ${ }^{1}$, (1) Tufan Gümüş², (1) Filiz İlhan Türkel ${ }^{3}$ \\ ${ }^{1}$ University of Health Sciences Turkey, Kayseri City Hospital, Clinic of General Surgery, Kayseri, Turkey \\ ${ }^{2}$ Ege University Faculty of Medicine, Department of General Surgery, İzmir, Turkey \\ ${ }^{3}$ Tuzla State Hospital, Clinic of Patology, İstanbul, Turkey
}

\section{Cite this article as: Patmano M, Gümüş T, Türkel Fì. A Rare Cause of Acute Appendicitis: Enterobius vermicularis.}

Turkiye Parazitol Derg 2021;45(3):220-222.

\begin{abstract}
Acute appendicitis is the most common intra-abdominal pathology that requires emergency surgery in general surgery clinics. The aetiology of acute appendicitis includes both infectious and non-infectious causes. Although parasitic diseases are rare in developed countries, they are more common in developing countries. The association between acute appendicitis and parasitic infections is unclear, and whether parasites are the cause of acute appendicitis is still under debate. In addition, many appendix parasites are encountered after appendectomy. In this study, we report a rare case of acute appendicitis caused by Enterobius vermicularis.
\end{abstract}

Keywords: Appendicitis, parasite, Enterobius vermicularis

Öz

Akut apandisit, genel cerrahi kliniklerinde en sık acil cerrahi girişim gerektiren batın içi patolojidir. Akut apandisit etiyolojisinde hem enfeksiyonlar hem de enfeksiyon dışı nedenler yer almaktadır. Paraziter hastalıklar gelişmiş ülkelerde ender görülmesine rağmen gelişmekte olan ülkelerde daha sık rastlanılmaktadır. Akut apandisit ile parazit enfeksiyonları arasındaki bağlantı net değildir. Parazitlerin akut apandisit sebebi olup olmadığı konusu halen tartışılmakla beraber, yapılan appendektomi ameliyatları sonrasında apendiks lümeninde çok sayıda parazite rastlandığ da bilinmektedir. Bu çalışmada, patoloji sonucuna göre Enterobius vermicularis'in neden olduğu, nadir görülen bir akut apandisit olgusu sunulmuştur.

Anahtar Kelimeler: Apandisit, parazit, Enterobius vermicularis

\section{INTRODUCTION}

Acute appendicitis is the most common intraabdominal pathology requiring urgent surgical intervention in general surgery clinics (1). Patients frequently present with anorexia and abdominal pain localized to the right lower quadrant within hours (2). The etiology of acute appendicitis includes both infections and noninfectious causes. Many non-infectious events in the right lower quadrant may mimic the clinical picture of acute appendicitis. Parasitic infections in the lumen of the appendix may mimic the acute appendicitis clinic by obstructing the lumen without causing an acute inflammation of the appendix $(1,3,4)$. Although parasitic diseases are rare in developed countries, they are more common in developing countries. Enterobius vermicularis (E. vermicularis) is the most common human parasite. E. vermicularis is both the most common parasitic agent in the gastrointestinal tract and the most common cause of gastrointestinal infection worldwide and it also causes appendicitis among parasitic diseases $(5,6)$.

E. vermicularis is an intestinal parasite that is located in the last part of the small intestine, the first part of the cecum and colon, which is more common in the cold climate regions of the underdeveloped countries and frequently affects children $(1,4)$. The most common spread in humans is the fecal-oral route and the eggs remain alive in the clothes and beds for two to three weeks, making it easy to spread (7). While itching is the most common symptom in perianal region in E. vermicularis infections; ileocolitis, enterocutaneous fistula, urinary tract infection, 
appendicitis, and mesenteric abscess may also be encountered (8). While the presence of E. vermicularis in the appendix may cause symptoms similar to appendicitis, histological evidence of acute inflammation is often not found $(9,10)$. Although the connection between acute appendicitis and parasitic infections is unclear and whether parasites are the cause of acute appendicitis is still debated, it is known that many appendicum luminescent parasites are encountered after appendectomy operations $(2,11)$. In this case report, we aimed to present a rare case of acute appendicitis caused by E. vermicularis.

\section{CASE REPORT}

A twenty-five-year-old female patient with no known concomitant disease was admitted to the emergency department with the complaint of abdominal pain that had started 1 day ago. As a result of the examinations performed, we were consulted. Physical examination of the patient revealed tenderness and rebound findings in the right lower quadrant. White blood cell sphere: 11.900/ $\mu \mathrm{L}$, hemoglobin: $12.3 \mathrm{~g} / \mathrm{dL}$, hematocrit: 37.6 , and biochemical values were normal. In the abdominal ultrasonography of the patient, a significant luminal structure was observed in terms of acute appendicitis with a diameter of $7.5 \mathrm{~mm}$ adjacent to the cecum. The patient was consulted with anesthesia and laparoscopic appendectomy was performed. The patient was discharged without any complication on the first postoperative day. On the $3^{\text {rd }}$ day after discharge, she was re-admitted due to abdominal pain anorexia. The patient's hemogram, biochemistry, C-reactive protein and abdominal ultrasonography were normal. Considering the pathology result of the patient, it was thought that abdominal pain may be due to parasites present in the intestine. The pathological result of the patient was reported as reactive lymphoid hyperplasia and parasite egg in the lumen (Figure 1). The patient was treated with infectious diseases for planning medical treatment.

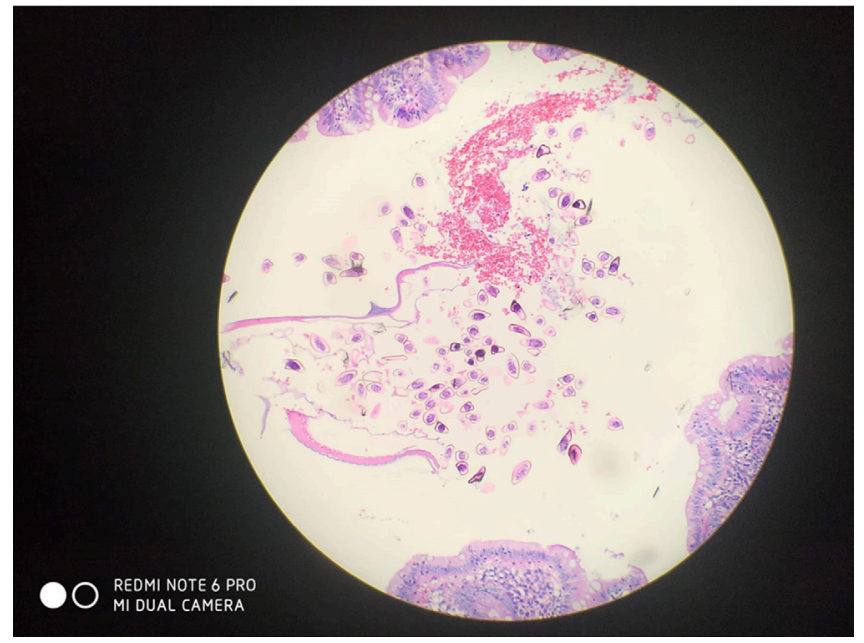

Figure 1. Parasitic eggs of Enterobius vermicularis in lumen at 200 magnification in hematoxylin-eosin stained appendicitis sections

\section{DISCUSSION}

Acute appendicitis is one of the most common emergency surgical pathologies. Nowadays, this disease can be fully cured by laparoscopic or open surgery. Parasitic infections are among the reasons that can mimic the acute appendicitis clinic. Acute appendicitis like right lower quadrant pain, nausea and vomiting may be seen clinically. Radiological imaging methods and laboratory findings are not helpful in differentiating the diagnosis of parasitic acute appendicitis. The definitive diagnosis is made by histopathological examination of the appendix and parasite eggs in the lumen. Acute appendicitis is seen more frequently especially in puberty and in males (7-9). Lymphoid hyperplasia in children, faecalitis in adults, tumors in the elderly are the most common causes of obstruction of the appendix lumen $(8,9)$. $E$. vermicularis is a common parasite located worldwide in the cecum and appendix vermiformis. In the study of Yildirim et al. (10) reported that four patients (3.8\%) had E. vermicularis and one patient (1\%) had Entamoeba histolytica in the appendicum lumen after 104 appendectomy operations. Pehlivanoğlu et al. (11) examined 3.222 appendectomy materials and the frequency of E. vermicularis was $0.74 \%$. Karatepe et al. (12) found normal histology in the histopathologic examination of appendectomas due to parasitic infection. Gastrointestinal infections due to $E$. vermicularis are among the most common helminth infections worldwide (13). Hasan et al. (14) have extensively examined whether E. vermicularis causes appendicitis, and researchers suggest that it is a clinical mimetic of appendicitis but does not produce typical inflammation. This infection is most commonly seen in children aged four to five years, but Kurt et al. (13) reported that appendectomy was most commonly detected in the $2^{\text {nd }}$ and $4^{\text {th }}$ decades of E. vermicularis. A female patient in the third decade (15). The finding of females having higher prevalence of E. vermicularis (58.1\% of cases) comes in agreement with E. vermicularis being more common in girls (16). It is known that the incidence of E. vermicularis varies between $0.2 \%$ and $41.8 \%$ in patients with appendicitis symptoms (17). The role of $E$. vermicularis in the cause of acute appendicitis remains controversial. Appendectomy alone is not an adequate treatment for patients whose appendectomies are found to contain E. vermicularis since surgery cannot eliminate the cause and will result in only one condition, anti-helminthic drugs should be recommended to patients after surgery $(14,18)$.

In conclusion, it is reported that inflammatory changes are rare in cases where parasite is detected in the appendix lumen $(5,10)$. In our study, the presence of $E$. vermicularis causes acute inflammation of the appendix lumen. It is important because it is a rare cause of acute appendicitis which needs medical treatment.

\section{* Ethics}

Informed Consent: Retrospective study.

Peer-review: Internally peer-reviewed.

\section{* Authorship Contributions}

Surgical and Medical Practices: T.G., Concept: M.P., F.İ.T., Design: M.P., T.G., Data Collection or Processing: M.P., T.G., Analysis or Interpretation: T.G., F.İ.T., Literature Search: M.P., F.I.T., Writing: M.P.

Conflict of Interest: No conflict of interest was declared by the authors.

Financial Disclosure: The authors declared that this study received no financial support. 


\section{REFERENCES}

1. Ahmadi MH, Seifmanesh M. Taeniasis Caused Appendicitis Without Local Tenderness: a Rare Case. Hospital Chronicles 2011; 6: 207-9.

2. Arca MJ, Gates RL, Groner JI, Hammond S, Caniano DA. Clinical manifestations of appendiceal pinworms in children: an institutional experience and a review of the literature. Pediatr Surg Int 2004; 20: 372-5.

3. Çallı G, Özbilgin M, Yapar N, Sarıoglu S, Özkoç S. Akut apandisit ve enterobiyaz ile taeniyaz: bir olgu sunumu [Acute appendicitis and coinfection with enterobiasis and taeniasis: a case report]. Turkiye Parazitol Derg 2014; 38: 58-60.

4. Lamps LW. Infectious causes of appendicitis. Infect Dis Clin North Am 2010; 24: 995-1018.

5. Özdil K, Karataş N, Zincir H. Halk Sağlığ1 Uygulamalarının Enterobius vermicularis' in Korunma ve Kontrolündeki Önemi. Nevşehir Bilim ve Teknoloji Dergisi 2020; 9: 154-63.

6. Mowlavi GH, Massoud J, Mobedi I, Rezaian M, Solaymani Mohammadi S, Mostoufi NE, et al. Enterobius vermicularis: a controversial cause of appendicitis. Iran J Public Health 2004; 33: 27-31.

7. Hashemi SA, Hosseyni Teshniz S, Vafaei F, Ganji A, Montazami Sadeghi M, Mizani A, et al. Incidence of Enterobius vermicularis in acute appendicitis: A systematic review and meta-analysis. J Acute Dis 2020; 9: 152-6.

8. Arca MJ, Gates RL, Groner JI, Hammond S, Caniano DA. Clinical manifestations of appendiceal pinworms in children: an institutional experience and a review of the literature. Pediatr Surg Int 2004; 20: 372-5.
9. Humes DJ, Simpson J. Acute appendicitis. BMJ 2006; 333: 530-4.

10. Yildirim S, Nursal TZ, Tarim A, Kayaselcuk F, Noyan T. A rare cause of acute appendicitis: parasitic infection. Scand J Infect Dis 2005; 37: 757-9.

11. Pehlivanoğlu B, Aydın Türk B, İşler S, Özdaş S, Abeş M. Findings in Appendectomies with Enterobius vermicularis Infection: Pinworm Is Not A Cause of Appendicitis. Turkiye Parazitol Derg 2019; 43: 21-5.

12. Karatepe O, Adas G, Tukenmez M, Battal M, Altiok M, Karahan S. Parasitic infestation as cause of acute appendicitis. G Chir 2009; 30: 426-8.

13. Kurt A, Calik I, Omerogullari Sener E, Akalp Ozmen S, Gelincik I. Appendectomy Materials With E. Vermicularis. Van Med J 2012; 19: 51-4.

14. Hasan A, Nafie K, El-Sayed S, Nasr M, Abdulmohaymen A, Baheeg M, et al. Enterobius vermicularis in appendectomy specimens; Clinicopathological assessment: Cross sectional study. Ann Med Surg (Lond) 2020; 60: 16872.

15. Dahlstrom JE, Macarthur EB. Enterobius vermicularis: a possible cause of symptoms resembling appendicitis. Aust N Z J Surg 1994; 64: 692-4.

16. Wendt S, Trawinski H, Schubert S, Rodloff AC, Mössner J, Lübbert C. The Diagnosis and Treatment of Pinworm Infection. Dtsch Arztebl Int 2019; 116: 213-9.

17. Sarıçam G, Karaca G, Pehlivanlı F, Yıldırım K. Nadir bir akut apandisit nedeni: Enterobius vermicularis. Van Tip Dergisi 2014; 21: 114-6.

18. Yabanoğlu H, Aytaç HÖ, Türk E, Karagülle E, Calışkan K, Belli S, et al. Parasitic infections of the appendix as a cause of appendectomy in adult patients. Turkiye Parazitol Derg 2014; 38: 12-6. 